\title{
The Impact of Mobile Technologies-integrated Cooperative Instruction Workshop for In-service Science Teachers
}

\author{
Duongdearn Suwanjinda*, Suchin Visavateeranon, Songpon Phadungphatthanakoon \\ School of Educational Studies, Sukhothai Thammathirat Open University, Thailand
}

Received May 21, 2020; Revised July 17, 2020; Accepted August 10, 2020

\section{Cite This Paper in the following Citation Styles}

(a): [1] Duongdearn Suwanjinda, Suchin Visavateeranon, Songpon Phadungphatthanakoon, "The Impact of Mobile Technologies-integrated Cooperative Instruction Workshop for In-service Science Teachers," Universal Journal of Educational Research, Vol. 8, No. 9, pp. 4287-4293, 2020. DOI: 10.13189/ujer.2020.080955.

(b): Duongdearn Suwanjinda, Suchin Visavateeranon, Songpon Phadungphatthanakoon (2020). The Impact of Mobile Technologies-integrated Cooperative Instruction Workshop for In-service Science Teachers. Universal Journal of Educational Research, 8(9), 4287-4293. DOI: 10.13189/ujer.2020.080955.

Copyright $(\mathrm{O} 2020$ by authors, all rights reserved. Authors agree that this article remains permanently open access under the terms of the Creative Commons Attribution License 4.0 International License

\begin{abstract}
The purpose of this research is to see the effect of a mobile technologies-integrated cooperative instruction (MTICI) workshop for in-service science teachers upon teachers' perception and their students' understanding and satisfaction. The participants were 30 science teachers and 136 students. The research tools were as follows: 1) The MTICI workshop for in-service science teachers, 2) a teachers' self-assessment form on understanding about the MTICI 3) lesson plans focused on MTICI regarding the topic of rivers and water quality, 4) a test of students' understanding in the topic of rivers and water quality and the students' satisfaction questionnaire regarding the use of mobile technologies of the teacher. Frequency, percentage, mean and standard deviation were used for data analysis. The results showed that (1) the teachers who have participated in the workshop perceived the use of mobile technologies in the science classroom with the highest level of average understanding; (2) the students' post-understanding of the topic of rivers and water quality was significantly higher than their pre-learning counterpart understanding at the .05 level of statistical significance; and (3) the students' overall satisfaction of the MTICI was at a high level.
\end{abstract}

Keywords Science Instruction, Cooperative Learning, Mobile Technology, School Science Teacher

\section{Introduction}

Cooperative learning as an instructional strategy provides opportunities for students to learn and work together. It encourages achievement, student discussion, active learning, student confidence and motivation [1-3]. Moreover, it has the potential to produce an engagement of students rather than other learning forms [4]. Teaching knowledge and skill and classroom management of teachers were important to increase cooperative learning effectiveness as well. In science subject area, cooperative learning, Jigsaw method based, resulted in higher levels of achievement [5].

Nowadays, Mobile technologies are part of most teachers and students' lives because there is an advantage in having the ability to communicate at unlimited times and locations. They can access photographic information and record ideas on a single device which can instantly share content with friends, colleagues or everyone on earth. Mobile technologies have potential as mixed media and unique learning resource for instruction. They can also promote cooperative learning and other innovative pedagogy [6-7].

The use of mobile technologies such as smartphones or tablets as learning media in science instruction provides an authentic imitation of scientific inquiry. These include supporting the posing questions, planning and using the inquiry for data collection, observation, analysis and 
interpretation of data, and creating explanations and arguments using evidence [8-9]. Mobile technologies are therefore ideal tools for supporting the inquiry process with the ability to access mixed media, data collection, communication, representation, information sharing, knowledge creation, linking, reference and analysis [10].

However, mobile technologies have not been fully utilized in science education, especially in supporting the measurement and exploration of phenomena in the real world. Almost all science teachers allow students to conduct inquiry separately (individually or in pairs or in small groups), and much of this inquiry is done in class.

From synthesis of research reports on learning by using mobile technologies during the years 2010-2015 of students from early childhood education to upper secondary level [11] revealed that (1) 40 percent of researchers designed activities that use mobile technologies that is consistent with learning behavior. (2) Science has been accounted for as much as 53 percent of the use of mobile technology (3) 56 percent studied the use of mobile technologies in primary schools. (4) 63 percent focus on the learning of students rather than mobile devices. (5) 50 percent of research on the use of mobile technologies occurred in the formal educational management context.

In addition, research on cooperative learning found that the use of mobile technologies have a positive relationship with the level of critical thinking of students [12]. The findings from important research such as speech and visual communication are important indicators of students' participation in the group. Mobile technologies play an important role in helping learners learn and improve their critical thinking.

Nevertheless, the previous result of our survey on 410 science teachers' opinion about using mobile technologies and cooperative learning found that they believed in using mobile technologies in science teaching will promote cooperative learning $(M=4.04, S D=0.78)$ and their classes and students are ready to use mobile technologies in science learning $(M=4.09, S D=0.89)$. Among 410 teachers, there were 147 teachers interested in participating in MTICI workshop.

Therefore, this research aimed to 1) develop science instruction workshop focusing on MTICI 2) study the results of the workshop through teachers' understanding of MTICI and students' learning achievement and satisfaction.

\section{Research Methodology}

This research was a quantitative approach, divided into two phases. In the first phase, a workshop program on MTICI was developed and administered to 30 science teachers under the Office of the Basic Education Commission, selected from those who applied to participate in the research project with high interest and had high experience in using mobile technology. They were 3 males (10 percent) and 27 females ( 90 percent) who taught $6^{\text {th }}$ grade to $12^{\text {th }}$ grade students. During the workshop, the teachers were attending lecture on cooperative learning and instructional technologies using mobile devices then worked in groups of five to design lesson plans that focus on MTICI. Each group of teachers had an opportunity to present their designed lesson plans to all participants and experts in science and technology education. After the presentation, three experts commented and gave feedbacks and suggestions for improving each designed lesson plan. After attending the workshop, the teachers' understanding of MTICI was measured and the results were analysed by using frequency, percentage, mean, and standard deviation.

In the second phase, the results of the workshop emphasized MTICI toward students were studied, a lesson plan in the topic of rivers and water quality designed by a group of 5 science teachers who taught $9^{\text {th }}$ grade students was selected and implemented to 136 students. The reason supporting the selection was the rivers and water quality lesson in $9^{\text {th }}$ grade which was expected to start in two weeks after the training process completed. The lesson plan (see appendix) had been improved by those teachers according to three expert comments before using it to teach their students. The students' pre and post understanding on the topic of rivers and water quality and satisfaction were assessed. Data was analysed by using frequency, percentage, mean, standard deviation and t-test.

\subsection{Research Instruments}

This research instruments consisted of experimental instrument and data-collecting instrument. An experimental instrument was a workshop of MTICI which included the following workshop activities; 1) lecture about cooperative learning and instructional technologies using mobile devices (Mobile phones, Tablet PCs, Laptops) and applications (Line Application, Edmodo, Kahoot, Quizizz, Zipgrade, Super Soomm, Microsoft Forms, Google Forms, Padlet, Coggle, Vidyard, AutoSurvey, AnswerGarden, QR Code Generator, Shorten URL, Pinterest, Facebook, Moodle, Zappar and HP Reveal), and 2) the practice of designing lesson plan that focusing on MTICI.

The data-collecting instruments developed by the researchers consisted of the following:

1. Teachers' self-assessment form of understanding about MTICI consisted of 35 items questionnaire which were a 5-point Likert scale. The scales ranged in categories of highest, high, medium, low, and lowest.

2. The test of students' understanding in the topic of river and water quality consisted of 10 multiple-choices items. 
3. The student's satisfaction assessment form consisted of 17 items questionnaire in three issues, cooperative learning, using programs/applications in science classrooms, and using portable mobile devices such as smartphones and tablets. They were a 5-point Likert scale. The scales ranged in categories from the highest, high, medium, low, and the lowest.

The validity of the data-collecting instruments were verified by three experts and the Item-Objective Congruence Index (IOC) were calculated. All three instruments had the IOC ranged between .67-1.00 which had the acceptable validity [13].

The test of students' understanding in the topic of river and water quality was pilot test with 30 students. The item difficulty ( $p$ value) of each test item ranged between $.25-.75$ (moderately difficult - moderately easy), item discrimination ( $\mathrm{r}$ value) of each test item ranged between .30-.70 (fair-good), and reliability (KR-20) was .79 (good for a classroom test).

\subsection{Context}

\subsubsection{Teachers}

The five teachers who implemented the designed lesson plan to the students in order to study the results of the workshop were one male and four females, ages between 30-40 years. They had experience in science teaching between 4-10 years and had experience in using mobile applications to manage science learning such as Kahoot and Facebook. From the survey of their interest in participating in the workshop, they believed that their classes were ready to use mobile technology to manage science learning and they were interested in participating in the workshop at the highest level.

\subsubsection{Students}

The $1369^{\text {th }}$ grade students had mobile phones either Android or IOS operating systems with cellular network connectivity. They had experience in using mobile phones in their classes to search for information. Some of them had experience in using applications in learning science such as
Kahoot and Facebook.

\subsubsection{Schools}

The five schools were two medium-sized, two large-sized school and one extra large-sized secondary schools. The schools had internet networks and allowed students to use their own devices for learning in classes.

\subsection{Data Collection}

Data collection of each phase as follow;

In the first phase, after the workshop had done, the teachers answered self-assessment form on understanding about MTICI.

In the second phase, the students took the pre and post tests of rivers and water quality and the student's satisfaction assessment form after the lessons have done.

\section{Research Results}

Research findings presented according to two research objectives were (1) results of development of MTICI for science teachers and (2) results of MTICI on students' understanding about river and water quality and satisfaction.

\subsection{Teachers' Understanding of MTICI}

Thirty science teachers who participated in the MTICI workshop understood the use of mobile technologies in science instruction at the highest level (Table 1). The designed lesson plans of the teachers in the first phase were consistent with MTICI which had been evaluated by three experts in science and technology education. These data reflected that the teachers understood the cooperative learning features at the highest level in every feature as follows; cooperative learning focusing on small group activities, learners have an exchange of ideas, students will interact within the group, each group consists of members with various knowledge and abilities, each person is truly involved in learning and in the success of the group. 
Table 1. Mean, standard deviation and the meaning of the teachers' perception of MTICI in science

\begin{tabular}{|c|c|c|c|}
\hline Item & (Mean $(\mathbf{M}$ & $\begin{array}{c}\text { Standard } \\
\text { (Deviation (SD }\end{array}$ & Meaning \\
\hline \multicolumn{4}{|l|}{ Understanding of Cooperative-Learning Features } \\
\hline Cooperative learning focused on small group activities. & 4.57 & 0.57 & highest \\
\hline Cooperative learning focused on exchange of students' ideas. & 4.67 & 0.48 & highest \\
\hline Cooperative learning focused on student intra-group interactive capability. & 4.63 & 0.49 & highest \\
\hline Cooperative learning focused on skill diversity among group members. & 4.63 & 0.49 & highest \\
\hline Cooperative learning focused on level of engagement among members. & 4.63 & 0.49 & highest \\
\hline \multicolumn{4}{|l|}{ Understanding of Important Components of Cooperative Learning } \\
\hline Positive interdependence & 4.69 & 0.47 & highest \\
\hline Face-to-face promotive interaction & 4.53 & 0.51 & highest \\
\hline Individual accountability & 4.53 & 0.51 & highest \\
\hline Interpersonal and small-group skills & 4.53 & 0.51 & highest \\
\hline Group processing & 4.50 & 0.51 & highest \\
\hline \multicolumn{4}{|c|}{$\begin{array}{l}\text { Understanding about using Cooperative Learning Techniques in the Science } \\
\text { Classroom }\end{array}$} \\
\hline STAD (Student Teams - Achievement Division) & 4.43 & 0.51 & high \\
\hline TGT (Team-Games Tournament) & 4.26 & 0.52 & high \\
\hline TAI (Team Assisted Individualization) & 4.23 & 0.43 & high \\
\hline CIRC (Cooperative Integrated Reading and Composition) & 4.33 & 0.48 & high \\
\hline Jigsaw & 4.63 & 0.61 & highest \\
\hline \multicolumn{4}{|l|}{ Understanding about using Programs/Applications in Science Classrooms } \\
\hline Line application & 4.80 & 0.41 & highest \\
\hline Shorten URL & 4.73 & 0.52 & highest \\
\hline QR Code Generator & 4.73 & 0.58 & highest \\
\hline Padlet & 4.73 & 0.52 & highest \\
\hline Coggle & 4.67 & 0.48 & highest \\
\hline Zipgrade & 4.90 & 0.31 & highest \\
\hline Quizizz & 4.67 & 0.55 & highest \\
\hline Pinterest & 4.57 & 0.63 & highest \\
\hline Zappar & 4.50 & 0.57 & highest \\
\hline PocketSights & 4.26 & 0.74 & high \\
\hline Screen Recording for Online Video Modules & 4.50 & 0.68 & highest \\
\hline Simple graphic design & 4.30 & 0.70 & high \\
\hline Search for media under the Creative Commons Convention & 4.30 & 0.65 & high \\
\hline Online Image-search based Material Development & 4.60 & 0.56 & highest \\
\hline Sound search sources & 4.33 & 0.66 & high \\
\hline Facebook & 4.90 & 0.40 & highest \\
\hline \multicolumn{4}{|c|}{$\begin{array}{l}\text { Understanding of using Portable Mobile Device such as Smartphones and Tablets in } \\
\text { Science Classrooms }\end{array}$} \\
\hline Designing science lessons & 4.83 & 0.37 & highest \\
\hline Creating learning media in science & 4.80 & 0.41 & highest \\
\hline Organizing learning activities in science & 4.83 & 0.37 & highest \\
\hline Evaluation of science learning & 4.70 & 0.65 & highest \\
\hline Total & 4.58 & 0.57 & highest \\
\hline
\end{tabular}

The teachers understood the important components of cooperative learning that focus on positive interdependence, face-to-face promotive interaction, individual accountability, interpersonal and small-group skills and group processing at the highest level.

The teachers scored a high level of understanding of the use of cooperative learning techniques in the science classroom in some techniques; Student Teams Achievement Division (STAD), Team-Games Tournament (TGT), Team Assisted Individualization (TAI), Cooperative Integrated Reading and Composition (CIRC). All scored high with the exception of a JIGSAW technique 
which was at the highest level.

All teachers understood using programs and applications in science classroom ranked at the highest level including 1) Line Application, 2) Shorten URL, 3) QR Code Generator, 4) Padlet, 5) Coggle, 6) Zipgrade, 7) Quizizz, 8) Pinterest, 9) Zappar, 10) Screen Recording for Online Video Modules, 11) Online Image-search based Material Development and 12) Facebook. While they understood PocketSights, simple graphic design, search for media under the Creative Commons Convention and using sound search sources at the high level.

In addition, all teachers understood using portable mobile devices such as smartphones and tablets in 1) designing science lessons, 2) creating learning media in science, 3 ) organizing learning activities in science, and 4) evaluation of science learning at the highest level.

\subsection{Students' Understanding in the Topic of Rivers and Water Quality}

Test result for understanding rivers and water quality of 136 students found that the percentage of students who answered questions correctly after studying increased for all 10 questions (Table 2 ) and was significantly higher than that of before at .05 level (Table 3 ).

Table 2. Questions, number of students who answered correctly and percentage increase

\begin{tabular}{|c|c|c|c|}
\hline \multirow{2}{*}{ Topics } & \multicolumn{2}{|c|}{$\begin{array}{c}\text { Number of students } \\
\text { who answered } \\
\text { correctly }\end{array}$} & $\begin{array}{c}\text { Percentage } \\
\text { increase }\end{array}$ \\
\cline { 2 - 4 } & before & after & \\
\hline Water temperature & 33 & 113 & 58.8 \\
\hline Acid and base (pH) & 41 & 126 & 62.5 \\
\hline $\begin{array}{c}\text { Dissolved oxygen (DO) } \\
\text { according to benchmarks }\end{array}$ & 33 & 134 & 74.3 \\
\hline $\begin{array}{c}\text { BOD according to } \\
\text { benchmarks }\end{array}$ & 28 & 103 & 55.1 \\
\hline Total Coliform Bacteria & 19 & 136 & 86.0 \\
\hline Fecal Coliform Bacteria & 48 & 111 & 46.3 \\
\hline $\begin{array}{c}\text { Animals in the group that } \\
\text { indicate very good water } \\
\text { quality }\end{array}$ & 24 & 109 & 62.5 \\
\hline $\begin{array}{c}\text { Animals in the group that } \\
\text { indicate good water } \\
\text { quality }\end{array}$ & 36 & 102 & 48.5 \\
\hline $\begin{array}{c}\text { Animals in the group that } \\
\text { indicate the water quality } \\
\text { at a fair level }\end{array}$ & 18 & 105 & 64.0 \\
\hline $\begin{array}{c}\text { Animals in the group that } \\
\text { indicate low water quality }\end{array}$ & 60 & 124 & 47.1 \\
\hline
\end{tabular}

Table 3. Mean and standard deviation of the students from answering questions about the topic of rivers and water quality and the t-score before studying and after studying

\begin{tabular}{|c|c|c|c|c|c|c|}
\hline $\begin{array}{c}\text { Number of } \\
9^{\text {th }} \begin{array}{c}\text { grade } \\
\text { students }\end{array}\end{array}$ & \multicolumn{2}{|c|}{ Before } & \multicolumn{2}{|c|}{ After } & \multirow{2}{*}{$\mathbf{t}$} & \multirow{2}{*}{$\mathbf{p}$} \\
\cline { 2 - 5 } & $\boldsymbol{M}$ & $\boldsymbol{S D}$ & $\boldsymbol{M}$ & $\boldsymbol{S D}$ & & \\
\hline 136 & 2.5 & 1.5 & 8.6 & 1.8 & $29.3^{*}$ & .000 \\
\hline $\mathrm{p}<.05$
\end{tabular}

\subsection{Students' Satisfaction}

The students who answered the questionnaire for satisfying MTICI of science teachers were $1369^{\text {th }}$ grade students.

When their teachers used mobile technologies for science instruction, the students' overall satisfaction was at a high level as shown in Table 4. The students satisfied cooperative learning $(M=4.1, S D=0.7)$, using programs and applications in science classroom $(M=4.0, S D=0.9)$, and using portable mobile devices such as smartphones and tablets $(M=4.3, S D=0.8)$.

Table 4. Mean, standard deviation and meaning of students' satisfaction to MTICI

\begin{tabular}{|l|c|c|c|}
\hline $\begin{array}{l}\text { Students' satisfaction to using } \\
\text { MTICI on the issues }\end{array}$ & M & SD & Meaning \\
\hline Cooperative learning & 4.1 & 0.7 & high \\
\hline $\begin{array}{l}\text { Using programs/applications in } \\
\text { science classrooms }\end{array}$ & 4.0 & 0.9 & high \\
\hline $\begin{array}{l}\text { Using portable mobile devices such } \\
\text { as smartphones and tablets }\end{array}$ & 4.3 & 0.7 & high \\
\hline Total & $\mathbf{4 . 1}$ & $\mathbf{0 . 8}$ & high \\
\hline
\end{tabular}

\section{Discussion and Conclusions}

The results of our study revealed that thirty science teachers who have participated in the workshop have good understanding on MTICI. Their designed lesson plans, which had been evaluated by three experts in science and technology education, were consistent with MTICI. Meanwhile, the implementation of the lesson plan using JIGSAW as the technique of cooperative learning (see appendix) in classrooms of five teachers who were the sample in the second phase resulted in their students having a high level of understanding and satisfied with this instruction. Teachers' understanding from the workshop helped them design lesson plan consistent with MTICI. Also, contexts, the readiness of students' own devices and internet network connectivity promoted students' learning and understanding. This evidence pointed out that the development of science instruction through the workshop can increase the teachers' understanding of MTICI and help them to create the lesson plans appropriate with the approach and students.

The teachers' understanding regarding cooperative learning by using mobile technologies as a learning tool was generally positive as the same as the finding of Heflin, Shewmaker, and Nguyen [12]. Furthermore, the students' understanding in the topic of rivers and water quality was at the high level after learning via MTICI. This result might have an effect on cooperative learning [14-15] and also revealed that JIGSAW technique improved students' achievement [5]. Additionally, the use of mobile technologies in instruction allowing students create and present content such as text, maps, sites, images, videos, about rivers and water quality is consistent with 
constructivist theory and social constructivist theory [16]. The students constructed their knowledge in practice. Learning activities allowed the students to construct new knowledge via inquiry or investigation process. Whereas, mobile technologies such as Pinterest application, Padlet application, Coggle application which used in this study was tools that help to find knowledge and brainstorm within group. Aside from online interactions; posing and commenting in the Facebook groups were considered to be social and situated learning experiences. The usage of mobile technologies in this study increased students' understanding and satisfaction is consistent with the study of Chen, Kao, Yu, and Sheu [17] which they provided appropriate mobile tools helped students to become capable and increase students' learning achievement.

Based on the findings of this research, these pointed out that the MTICI workshop improved the science teachers' perception of MTICI and could help them successfully integrated mobile technologies in their classroom instruction. Additionally, the implementation of the teachers' designed lesson plan in the topic of rivers and water quality had impact on the understanding and satisfaction of students positively. However, the prior technological experience and attitude might be important factors affecting MTICI workshop's effectiveness. Meanwhile, the internet network, mobile devices might also be important factors affecting effectiveness of science instruction focusing on MTICI.

We hope that the MICTI knowledge that the science teachers gained in the workshops will be used for further instruction developments. Nowadays, the situation where social distancing is important to maintain due to the COVID-19 pandemic, such instruction focusing on MTICI is an interesting option for classrooms. Thus, this research might help to be an example in the professional development of science teachers.

\section{Acknowledgments}

The author would like to acknowledge the financial support of Distance Education Research Grant, Institute for Research and Development, Sukhothai Thammathirat Open University.

\section{Appendix}

Example of mobile technologies-integrated cooperative instruction lesson plan for $9^{\text {th }}$ grade students "rivers and water quality"

\section{Objectives}

After studying, students can

1. Check the water quality in the local water source

2. Analyze water quality in local water sources

3. Identify the causes of the problems of local water source usage

4. Identify the impacts of the problems of local water source usage

5. Propose guidelines for prevention and resolution of water sources in the area and disseminate to other people

Mobile technologies-integrated cooperative (JIGSAW) instructions

\begin{tabular}{|c|c|c|}
\hline Steps & Activities & Mobile technologies-integrated \\
\hline 1 & $\begin{array}{l}\text { Assign each student to a "home group" of } 3 \text { students which reflect a } \\
\text { range of student abilities. } \\
\text { 1.1 The teacher discusses with the students about the water situation } \\
\text { and takes the students to explore local water sources. } \\
\text { 1.2 Students create learning resources based on locations on a GPS. } \\
\text { 1.3 Students record the survey results in an Activity Sheet } 1 \text { "physical } \\
\text { characteristics survey of water resources". } \\
\text { 1.4 Students jointly identify the problematic issues from a physical } \\
\text { characteristic survey of water resources. }\end{array}$ & $\begin{array}{l}\text { Google Map, PocketSight Application, Line } \\
\text { Application, Facebook } \\
\text { Padlet Application / Coggle Application }\end{array}$ \\
\hline 2 & $\begin{array}{l}\text { Each member of "home group" is assigned to study the content of } \\
\text { each section which are } 1 \text { (Physical water quality, 2( Chemical water } \\
\text { quality, and 3( Biological water quality. }\end{array}$ & Pinterest Application \\
\hline 3 & $\begin{array}{l}\text { Students create "expert groups" that consist of students across "home } \\
\text { groups" who will study the same section. } \\
\text { - Each group of students jointly inspected the water quality } \\
\text { according to the assigned topic. } \\
\text { Teachers recommend internet resources and media searches } \\
\text { under the Creative Commons Convention for students. }\end{array}$ & $\begin{array}{l}\text { Search for media under the Creative Commons } \\
\text { Convention } \\
\text { Smart Phone, iPad }\end{array}$ \\
\hline 4 & $\begin{array}{l}\text { Expert group members return to "home groups" } \\
4.1 \text { Students exchange knowledge gained from "expert groups" with } \\
\text { home group members. Students summarize their newfound } \\
\text { knowledge as a home group concept prepare to present to class. } \\
4.2 \text { Each group presents their newfound knowledge to their class. }\end{array}$ & $\begin{array}{l}\text { Saving screen to online video, Vidyard Application, } \\
\text { Facebook }\end{array}$ \\
\hline
\end{tabular}




\section{REFERENCES}

[1] D. Johnson, R. Johnson. Learning together and alone: overview and metaanalysis. Asia Pacific Journal of Education, Vol.22, 95-105, 2002.

[2] Y. Lou, P. Abrami, J. Spence, C. Poulsen, B. Chambers, S. d'Apollonia. Within-class grouping: a meta-analysis. Review of Educational Research, Vol.66, 423-458, 1996.

[3] R. Slavin. Research on cooperative learning and achievement: what we know, what we need to know. Contemporary Educational Psychology, Vol.21, 43-69, 1996.

[4] R. Slavin, E. A. Hurley, A. Chamberlain, Cooperative Learning and achievement: Theory and research. In W. Reynolds \& G. Miller (Eds.) Handbook of Psychology: Vol. 7. Educational Psychology (pp. 177-198), John Wiley, New York, 2003.

[5] Karacop, A. The effects of using jigsaw method based on cooperative learning model in the undergraduate science laboratory practices, Universal Journal of Educational Research, Vol.5, No.3, 420-434, 2017.

[6] Y. J. Lan, Y. T. Sung, K. E. Chang. A mobile-device-supported peer-assisted learning system for collaborative early EFL reading. Language Learning \& Technology, Vol.11, 130-151, 2007.

[7] J. Roschelle, K. Rafanan, R. Bhanot, G. Estrella, B. Penuel, M. Nussbaum, et al. Scaffolding group explanation and feedback with handheld technology: impact on students' mathematics learning. Educational Technology Research and Development, Vol.58, 399-419, 2010.

[8] C. Herodotou, E. Villasclaras-Fernández, M. Sharples. The design and evaluation of a sensor-based mobile application for citizen inquiry science investigations. In Open Learning and Teaching in Educational Communities (pp. 434-439).

Springer International Publishing, 2014.

[9] R. Wilson, J. Goodman, L. Bradbury, L. Gross. Exploring the use of iPads to investigate forces and motion in an elementary science methods course. Contemporary Issues in Technology and Teacher Education, Vol.13, No.2. Online available from http://www.citejournal.org/vol13/iss2/scienc e/article1.cfm., 2013.

[10] Y. Song. Bring Your Own Device (BYOD) for seamless science inquiry in a primary school. Computers \& Education, Vol.74, 50-60, 2014.

[11] H. Crompton, D. Burke, K. H. Gregorya. The use of mobile learning in PK-12 education: A systematic review. Computers \& Education, Vol.110, 51-63, 2017.

[12] H. Heflin, J. Shewmaker, J. Nguyen. Impact of mobile technology on student attitudes, engagement, and learning. Computers \& Education, Vol.107, 91-99, 2017.

[13] R. C. Turner, L. Carlson. Indexes of Item-Objective Congruence for multidimensional items, International Journal of Testing, Vol.3, No.2, 163-171, 2003.

[14] R. S. Siegler, D. W. Braithwaite. Numerical development, Annual Review of Psychology, Vol. 68, 187-213, 2017.

[15] Y. J. Lee, C. H. Chao, C. Y. Chen. The influences of interest in learning and learning hours on learning outcomes of vocational college students in Taiwan: using a teacher's instructional attitude as the moderator. Global journal of engineering education, Vol. 13, No. 3, 140-153, 2011.

[16] J. R. Ouyang, N. Stanley. Theories and research in educational technology and distance learning instruction through blackboard, Universal Journal of Educational Research, Vol.2, No.2, 161-172, 2014.

[17] Y-S. Chen, T-C. Kao, G-J. Yu, J-P. Sheu. A mobile butterfly-watching learning system for supporting independent learning. Proceedings of the 2nd International Workshop on Wireless and Mobile Technologies in Education. JungLi, Taiwan: IEEE Computer Society, 11-18, 2004. 